\title{
ACQUIRING AND APPLYING KNOWLEDGE IN TRANSNATIONAL TEAMS: THE ROLES OF COSMOPOLITANS AND LOCALS ${ }^{\bullet}$
}

\author{
Martine R. Haas \\ Cornell University \\ School of Industrial and Labor Relations \\ 365 Ives Hall, Ithaca, NY 14853
}

tel: (607) 2553048

fax: (607) 2552261

e-mail: martine_haas@cornell.edu

March 1, 2006

Forthcoming in Organization Science

\footnotetext{
- I am very grateful to Ann Majchrzak and the anonymous reviewers for their feedback, to Richard Hackman, Morten Hansen, Peter Marsden, Nitin Nohria, and Mitchell Orenstein for their support and guidance throughout this project, to Don Bergh, Chris Collins, and Melissa Thomas-Hunt for helpful comments on earlier drafts, and to the managers and teams at Quorum. The research was funded by the Harvard Business School and by the Hauser Center for Nonprofit Organizations at Harvard University. I also thank the International Management Division of the Academy of Management for nominating this paper for the 2005 William H. Newman Award for best paper based on a recent dissertation.
} 


\title{
ACQUIRING AND APPLYING KNOWLEDGE IN TRANSNATIONAL TEAMS: THE ROLES OF COSMOPOLITANS AND LOCALS
}

\begin{abstract}
This paper examines the roles of cosmopolitans and locals in transnational teams that work on knowledge-intensive projects. I propose that cosmopolitan and local team members can help their teams to acquire and apply knowledge more effectively, by bringing both internal and external knowledge to their teams and enabling them to more successfully transform this knowledge into improved project performance. Findings from a study of 96 project teams at an international development agency reveal that the roles of cosmopolitans and locals were complex and sometimes valuable, but cosmopolitans offered greater benefits than locals and too many of each could hurt. Implications for theory and research on international management, virtual teams, exploration and exploitation, and organizational knowledge are discussed.
\end{abstract}

Keywords: knowledge, transnational teams, cosmopolitans and locals, exploration and exploitation. 
To perform and compete successfully, transnational organizations must strive to achieve worldwide innovation, global integration, and local differentiation simultaneously (Bartlett and Ghoshal 1989; Nohria and Ghoshal 1997). Strategy and international management scholars increasingly view the creation, dissemination, and utilization of knowledge as critical to addressing these strategic imperatives (e.g., Grant 1996; Kogut and Zander 1993). A knowledge-based view of the firm is particularly relevant where the work demands continuous exploration for new knowledge and exploitation of existing knowledge (March 1991). In transnational organizations, such knowledge-intensive work often is projectbased and carried out by teams (e.g., Gibson and Cohen 2003; Kirkman et al. 2001; Snow et al. 1996). Because the members of these teams vary in their levels and types of experience, their contributions to the critical processes of acquiring and applying knowledge may vary accordingly (Jackson et al. 2003). This raises the question of whether team members with different levels and types of experience facilitate these processes to different extents and in different ways.

This paper examines knowledge acquisition and application in transnational teams by using a team member classification scheme that distinguishes between cosmopolitans, locals, and others, where “cosmopolitans” are individuals with broad experience in many countries, “locals” are individuals with deep experience in the project country, and “others” have neither very extensive global experience nor very extensive local experience though they may have some (cf. Kanter 1995; Tung 1998). ${ }^{\mathrm{i}}$ As transnational organizations seek to seize new opportunities and tackle problems around the world, they often rely on team members who are neither cosmopolitans nor locals, but organizations that recognize the need to deliver projects that are both globally informed and locally tailored frequently try to include at least some individuals with extensive global experience and others with considerable local experience on their project teams.

While research on cosmopolitans and locals in the context of transnational organizations is very limited, classifying team members as cosmopolitans, locals, or others offers benefits that distinguish this approach from more established paradigms that classify them according to attributes such as nationality, culture, location, or expatriate status. First, these categories fit well with a focus on knowledge-intensive 
work because they are based on variations in the levels and types of experience among individuals rather than on attributes that have less obvious relevance for such work. Second, these categories provide a way to conceptualize and address the organizational challenge of balancing global integration with local differentiation at the level of the work units that address this challenge daily, by classifying the members of project teams according to their global versus local experiences and considering the different roles played by members with such different experiences in their teams. Categorizing individuals as cosmopolitans, locals, or others thus offers insight into the potential contributions of different individuals to knowledge acquisition and application in transnational teams.

Consistent with prior research, in the theory and hypotheses that follow I adopt a broad definition of "knowledge” as an organized body of information, data, intelligence, or advice (Huber 1991), including explicit knowledge in the form of facts, analysis, and best practices that can be codified and communicated through documents as well as tacit knowledge such as insights, intuition and applied assumptions that are harder to articulate and transfer (cf. Gupta and Govindarajan 1991; Kogut and Zander 1992; Majchrzak et al. 2004). “Internal knowledge” refers to knowledge possessed by the team members themselves, while "external knowledge” refers to knowledge from sources outside the team (cf. Cummings 2004; Menon and Pfeffer 2003). After explicating the concepts of cosmopolitans and locals, I develop hypotheses that address their potential roles in knowledge acquisition and application, and test these hypotheses using survey data and project quality ratings from a multi-method field study.

\section{THEORY AND HYPOTHESES}

\section{Cosmopolitans and Locals}

The usefulness of distinguishing categorically between types of individuals is well established in the international management and transnational team literatures. In international management research, a distinction is commonly drawn between host-country nationals and expatriates who are assigned to live and work in a country other than their home base. The concept of expatriates is important for human resource management issues such as compensation, socialization, acculturation, repatriation, and 
compensation (e.g., Tung 1987), and it also provides insight into how transnational organizations coordinate and control their subsidiaries (e.g., Edstrom and Galbraith 1977). Some recent research also has begun to consider the possible strategic benefits of expatriate assignments for the creation and transfer of knowledge (e.g., Bjorkman et al. 2004; Hocking et al. 2004; Lyles and Salk 1996). For example, Tsang (2001) found that expatriate managers played a critical role in knowledge transfer in 18 China-invested enterprises, and Belderbos and Heijltjes (2005) found that knowledge creation and learning motivated the appointment of expatriates to senior positions in 844 Japanese manufacturing affiliates in Asia. The concept of expatriates has been criticized for being excessively broad, however, as it includes individuals with levels of international experience that range from low to high (Baruch and Altman 2002; Mendenhal and Oddou 1986). The concept is also limiting, since it overlooks non-expatriates who may have substantial international experience too. The cosmopolitan-local classification scheme addresses these critiques of expatriate studies by explicitly categorizing team members according to their experience.

Taking a different approach, the transnational team research usually distinguishes between team members according to their nationality, culture, or location. Because values, social behavior, and conceptualizations of self differ across countries (Hofstede 1980; Markus and Kitayama 1991; Triandis 1989), national and cultural diversity can impede decision-making within teams (e.g., Earley and Mosakowski 2000; Elron 1997; Hambrick et al. 1998; Kirkman and Shapiro 1997), and knowledge transfers across cultures can be impeded by problems of cross-cultural translation (Bhagat et al. 2002). Geographic dispersion also can affect communication, cohesion, and trust in virtual teams (e.g., Hinds and Kiesler 1995; Jarvenpaa and Leidner 1999; Maznevski and Chudoba 2000). In transnational organizations, however, team members from different nationalities, cultures, or locations often share much in common, while members with surface similarities in nationality, culture, or location often share little else (cf. Lau and Murninghan 1998). Additionally, these sources of heterogeneity in team composition do not directly capture variation in the global or local experiences of the team members. By categorizing team members according to their levels of global and local experience, the cosmopolitan- 
local classification scheme focuses attention on an important source of variation among team members and addresses this gap in the literature.

The conceptual categories of cosmopolitan and locals are rooted in sociological theories of role orientations. Like the expatriate and transnational team studies, these theories classify individuals as either belonging or not belonging to distinct categories, rather than assigning each individual a rating of cosmopolitanism and localism from low to high. In Merton’s (1957) analysis of influential community members, locals were identified as individuals whose interests were confined to the community, while cosmopolitans were individuals who were oriented to the world beyond this community and regarded themselves as part of that wider world. Gouldner (1957) developed the distinction in an organizational context, where he defined locals as employees whose primary loyalty was to the employing organization, and cosmopolitans as employees who were oriented more toward their external professional communities.

More recently, the concepts of cosmopolitans and locals have also been invoked in the international management literature (e.g., Kanter 1995; Ralston 1996; Tung 1998), although here their definitions are not well established. Kanter (1995: 22) defined cosmopolitans perhaps most evocatively in the transnational context, stating that: “Cosmopolitans are card-carrying members of the world class often literally card-carrying, with passports or air tickets serving to admit them... Comfortable in many places and able to understand and bridge the differences among them, cosmopolitans possess portable skills and a broad outlook.” In a study of 409 expatriates on assignment to 51 countries around the world, Tung (1998) developed Kanter’s conceptualization of cosmopolitans as individuals who are rich in the three intangible assets of “concepts, competence, and connections” (Kanter 1995: 23) by arguing that an effective way of developing these assets is to send managers on international assignments where they can assume a broader range of duties and responsibilities. Describing her sample, Tung (1998: 128) further noted: “Contrary to popular perceptions that Americans are insular, the American expatriates in this study are quite cosmopolitan. A vast majority of them have lived and/or worked for an extended number of years abroad and over one-half are bilingual or multi-lingual.” The limited prior research in this area thus 
suggests that experience living and working abroad and speaking foreign languages are qualifications for cosmopolitan status.

To build on this prior research while grounding the cosmopolitan and local categories in systematic definitions appropriate to the transnational context, this paper defines cosmopolitans and locals in terms of the attributes identified by Tung (1998). Cosmopolitans are identified as individuals who have lived and worked in multiple countries and speak several languages, while locals are identified as individuals who have lived and worked in the project country and speak the local language. These definitions are neither mutually exclusive nor mutually exhaustive, as some individuals might qualify as both while others might not qualify as either cosmopolitans or locals in a particular setting. To establish the value of these conceptual categories, the potential contributions of cosmopolitans and locals to knowledge acquisition and application in project teams are considered in four sets of hypotheses, summarized in Figure 1.

----- Insert Figure 1 about here -----

\section{Knowledge Acquisition}

Before they can apply knowledge to their projects, teams first must acquire that knowledge. This typically occurs in two main ways: by bringing in team members who possess relevant prior knowledge, and through exploration activities focused on gathering knowledge from sources outside the team. ${ }^{\text {ii }}$

Bringing in individuals with relevant prior knowledge as team members adds to the team's stock of internal knowledge. Locals who have lived and worked in the country and speak the language can be expected to bring a wealth of country knowledge to their teams, in the form of insight into the local environment and conditions relevant to the project such as the local economy, politics, culture, business customs, demands and tastes, infrastructure, and resources (cf. Lord and Ranft 2000; Makino and Delios 1996). In contrast, because cosmopolitans typically possess specialized knowledge that has proven valuable for assignments across the world, they can be expected to bring substantial technical knowledge to their teams, in the form of skills, competencies, and expertise relevant to the functional requirements of the work (cf. Obstfeld 2005). Cosmopolitans may possess some country as well as technical knowledge 
while locals may posses some technical as well as country knowledge, but there is no reason to expect cosmopolitans to bring more country knowledge than non-cosmopolitans or locals to bring more technical knowledge than non-locals. Hence, compared to teams that include fewer locals or cosmopolitans, the hypotheses concerning the acquisition of internal knowledge (upper-left quadrant in Figure 1) are:

H1a: Teams that include more local members will have more internal country knowledge.

H1b: Teams that include more cosmopolitan members will have more internal technical knowledge.

Exploration activities focused on gathering knowledge from experts or document sources outside the team provide external knowledge for the team. Locals can help their teams to gather more country knowledge relevant to the project because their familiarity with the context and personal connections enable them to identify better knowledge sources within the country and access those sources more easily than non-locals (cf. Lord and Ranft 2000; Makino and Delios 1996). They also may be able to more readily secure the attention and cooperation of local experts outside the team because their credibility and personal ties create trust, a sense of obligation, or expectations of reciprocity in the future (cf. Levin and Cross 2004; McEvily et al. 2003). For parallel reasons, cosmopolitans can help their teams to gather more technical knowledge relevant to the project. The diverse international experiences of cosmopolitans position them to know of more diverse and possibly better sources of technical knowledge than noncosmopolitans, and to have easier access to those sources and greater ability to obtain knowledge from them (cf. Hansen, 1999; Reagans and McEvily 2003). Cosmopolitans may gather country knowledge and locals may gather technical knowledge too, but there is no compelling reason to expect them to distinguish themselves in these ways. Thus, the hypotheses concerning the acquisition of external knowledge (upper-right quadrant in Figure 1) are:

H2a: Teams that include more local members will gather more external country knowledge.

H2b: Teams that include more cosmopolitan members will gather more external technical knowledge.

\section{Knowledge Application}


Once a team acquires internal or external knowledge, it must exploit that knowledge by applying it to improve project performance. For many teams in knowledge-intensive organizations, a critical measure of successful knowledge application is the quality of the project delivered to a client (Starbuck 1992). Other efficiency-based measures such as product development speed or project expenditures can be important too, but even projects that are completed swiftly or under budget often ultimately succeed or fail on their quality. Hence, the hypotheses that follow focus on the extent to which more internal knowledge within the team and more external knowledge gathering result in higher quality projects.

Locals can help their teams to interpret and customize internal knowledge in ways that are locally informed and appropriate by drawing on the "cultural toolkits” developed through their experience in the project country (Swidler 1986). Their perspectives can be valuable for applying country knowledge: for example, a local might provide insight into the reasons for the success of a recent marketing campaign in the south of the project country and help the team to identify which elements should be replicated or avoided in the north. Their perspectives can be valuable for applying technical knowledge too: for example, the local might advocate caution when the team is considering a product distribution strategy that worked in another country by pointing out that the transport infrastructure in the project country is less developed. Meanwhile, cosmopolitans can help their teams to calibrate and contextualize internal knowledge in ways that improve project quality. Their broad experiences in many countries increase their capacity for analogical reasoning, enabling them to discern patterns across situations and offer creative ideas (cf. Sutton and Hargadon 1996), and also build cultural intelligence, which sensitizes them to crosscultural differences and helps them make sense of unfamiliar contexts in new countries (Earley and Mosakowski 2004). Again, their perspectives can be valuable for applying country as well as technical knowledge: for example, a cosmopolitan might respond to country data on local literacy barriers to the use of a new product by explaining how other countries have addressed similar problems, or suggest that public sector budgeting expertise gained in Western Europe is unlikely to apply well in a developing country. Their potential contributions thus suggest that both cosmopolitans and locals can help their teams to benefit more from their internal country as well as technical knowledge, as these team members can 
exploit their own knowledge and that of the other team members more effectively. Hence, the hypotheses concerning the application of internal knowledge (lower-left quadrant in Figure 1) are:

H3a: The relationship between internal knowledge (both country and technical) and project quality will be more positive for teams that include more local members.

H3b: The relationship between internal knowledge (both country and technical) and project quality will be more positive for teams that include more cosmopolitan members.

Locals and cosmopolitans can help their teams to more effectively apply not only their internal knowledge but also the knowledge gathered from external sources during the project. Through their prior local and global experiences they develop absorptive capacity that helps them to sort higher from lower quality knowledge and thus manage the information overload challenges associated with knowledge gathering (cf. Huber 1991; Szulanski 1996; Zahra and George 2002). Together with their cultural and cross-cultural toolkits, this absorptive capacity also enables them to interpret and adapt both country and technical knowledge in ways that are more globally calibrated or locally informed (cf. Athanassiou and Nigh 2000). For example, locals can draw on their understanding of local tastes to interpret information about retail competitors in the project country or to apply information about the likely impact of retailing best practices from other countries. Cosmopolitans can draw on their global experiences to offer insight into whether such best practices transfer well across countries or to assess the problems facing local retailers against benchmarks drawn from other countries. Both cosmopolitans and locals thus can facilitate the successful application of external country as well as technical knowledge, increasing the benefits of external knowledge for project quality. Therefore, the last set of hypotheses (lower-right quadrant in Figure 1) is:

H4a: The relationship between external knowledge (both country and technical) and project quality will be more positive for teams that include more local members. 
H4b: The relationship between external knowledge (both country and technical) and project quality will be more positive for teams that include more cosmopolitan members.

\section{METHODS}

The hypotheses were tested using data collected during a multi-method field study conducted at “Quorum” (a pseudonym), a leading international development agency with over 10,000 employees and 100 country offices. In its team-based project work, human resource quality, and work processes and outputs, as well as its size and scope, Quorum was similar to other knowledge-intensive organizations such as global consulting firms, investment banks, or think tanks (cf. Starbuck 1992). Over a two year period, I studied Quorum teams that were engaged in projects for clients that were usually national or regional government agencies. The projects involved designing major economic and social development programs that were then backed by multi-million dollar financial loans or providing detailed technical analysis and advice on specific development issues.

The study began with a qualitative data collection phase during which I conducted extensive interviews lasting between one and three hours each. I gained an initial overview of the organization’s functions and operations through 20 interviews with managers and staff in the areas of strategy and change management, knowledge management, project quality monitoring, and human resources. Next, I conducted 18 semi-structured interviews with the leaders and members of project teams based at Quorum’s U.S. headquarters, and 7 additional interviews in Russia, where I visited Quorum’s Moscow office. I typically asked these interviewees to describe a project on which they were currently working, probing for specific details about the team members, their work, and the problems they encountered. I conducted another 25 interviews as part of detailed case studies of seven teams, interviewing the leader of each team and all the available members who were engaged in the team's work at the time. I also observed team meetings and read project materials that were generated as these teams worked. Before describing the quantitative data used to test the hypotheses, I draw on these qualitative data to illustrate the characteristics of teams and their work at Quorum (see also Haas 2005). 


\section{Teams at Quorum}

A new project began when a senior manager assigned a team leader to assemble a team and carry out the work. ${ }^{\text {iii }}$ Each interdisciplinary team was composed of functional experts who were brought together for a particular project, joining and leaving the team at different points. The team members were all highly qualified, often with Ph.D.s and substantial work experience. A team typically included economists, technical specialists, and social scientists with expertise in diverse fields ranging from public finance to infrastructure engineering to environmental issues. Most team members were full-time employees but some were external consultants. The majority of their work involved collecting, analyzing and applying facts and figures, information, advice, and best practices from widespread experts and data sources, preparing detailed written reports, and presenting their findings and recommendations to the client. Recognizing the centrality of knowledge accumulation and dissemination to its mission of advancing economic and social development around the world, Quorum had launched a high-profile knowledge management initiative five years prior to this study, investing in website development, document databases, communities of practice, help desks, and expert directories. This initiative had been highly acclaimed and Quorum was widely regarded as a leader in knowledge management practices.

Quorum teams were highly international in their work and structure. The team members could be based at headquarters, where most of Quorum's employees were located, in the client country office, or elsewhere. The work usually involved extensive travel, as team members who were not based in the client country flew in regularly to gather information and meet with the client agencies, while those who were based in the client country flew to headquarters and to other countries for more information gathering. Given their geographic spread and frequent travel, the team members could not readily be classified as expatriates or host-country nationals. Many were neither because they were based outside the client country. Most teams included members of diverse nationalities because Quorum based its hiring policy on national quotas and endeavored to staff its teams with functional experts regardless of nationality. This national diversity was rendered relatively unimportant, however, by other cross-cutting affiliations that gave the nationals of different countries much more in common than divided them, including highly 
prized shared identities as members of the organization, elite professions (particularly economics) and an international educated class. Nationality thus was not a very salient source of team member differences.

The categories of locals and cosmopolitans were more useful in capturing salient differences among team members at Quorum. Some team members were clearly identifiable as locals because they had lived and worked in the client country for many years and spoke the local language. For example, a local member of a West African urban infrastructure team had spent years living in the client country and working with other development agencies there before joining Quorum, and spoke two local dialects. Others were clearly identifiable as cosmopolitans because they had lived and worked in many countries and spoke multiple languages. Another member of the same team, for example, was a native of Argentina, spoke Spanish, French, Arabic, and English, and had worked and lived in Kenya, Uganda, Colombia, and Haiti. However, many team members had lived and worked in one or two countries only (often the U.S. and their home country), and were not multilingual. Most Quorum teams thus included a mix of locals, cosmopolitans, and others. The mix of such members was incidental rather than intentional, however, as team staffing was driven primarily by functional expertise and availability, and the unpredictable nature of the projects precluded matching particular mixes to particularly promising or challenging projects.

\section{Dependent and Independent Variables}

The quantitative data used to test the hypotheses came from a random sample of financial and technical projects drawn from the population of all projects completed in the previous year, as part of a high-level initiative to monitor project quality at Quorum. ${ }^{\text {iv }}$ When a team was selected for evaluation by Quorum's quality monitoring unit, I sent an extensively pre-tested survey to all the members of the team. The front page identified the project that the respondent was to focus on, but the respondents were not asked to report their names, functions, or nationalities to alleviate concerns about compromising anonymity. Surveys were sent to 1021 members of 120 teams whose projects were selected for quality evaluation in the year of the study (60 financial and 60 technical teams). Responses were received from 550 team members (response rate $=54 \%$ ). To ensure that the team-level measures were not based solely on responses from team members who were only peripherally involved in the project, the surveys 
identified respondents as core or non-core members and teams only qualified for inclusion in the study if at least $50 \%$ of their core team members responded (Hackman 2002). Using this criterion, 96 teams qualified for inclusion (50 financial and 46 technical teams; qualifying rate $=80 \%$ ), and data from the 485 members of these teams were used in the analyses.

The project quality measure was an ordinal rating of 1 "marginal or unsatisfactory” (project has major deficiencies), 2 "satisfactory” (project meets all client needs without major deficiencies), or 3 "highly satisfactory” (project represents best practice). The ratings for each project were determined by customized panels of two or more respected experts with no previous connections to that project, assembled by the quality monitoring unit. Each project was evaluated by a different expert panel, but prior tests of the evaluation methodology had found that different panels were highly likely to rate the same project similarly. The panelists reviewed the project documents, interviewed the team leader, and rigorously evaluated the project on a set of clearly specified quality dimensions using more than 100 detailed questions developed through extensive consultation within Quorum and with its stakeholders. The overall rating assigned to a project took into account the panelists' full understanding of its unique circumstances as well as the numerical scores on these quality dimensions. Of the 96 projects in the dataset, $14 \%$ received an overall rating of $1,70 \%$ received a rating of 2 , and $16 \%$ received a rating of 3 . $^{\mathrm{v}}$

To measure the team's internal technical knowledge and internal country knowledge, the survey asked the team members: "Prior to the start of this project, how much relevant technical/country knowledge did you personally have?” (scales from 1 “very little relevant knowledge” to 5 “a lot of relevant knowledge”). Technical knowledge was defined as "knowledge about the technical aspects of the work - the professional skills, competencies, and expertise relevant to the project.” Country knowledge was defined as "knowledge about the local environment - the country-specific conditions relevant to the project.” Team level measures were constructed by averaging the responses of the team members, and the two scales were combined to create a measure of the team's total internal knowledge.

To measure the external technical knowledge and external country knowledge gathered by the team, the survey asked: "During the course of the project, how much relevant technical/country 
knowledge did you gather from (a) the country office? (b) the rest of the organization? (c) the client country (including the client government, intended project beneficiaries, and local stakeholders)? (d) the global community (including global NGOs, donors, etc)?” (scales from 1 “very little relevant knowledge” to 5 "a lot of relevant knowledge"). These four sources of external knowledge were identified as those that were most meaningful to Quorum team members during the preliminary qualitative research. The team members' responses to each set of four questions were averaged to create team-level measures of external technical knowledge (Cronbach’s alpha $=0.70)$ and external country knowledge (Cronbach’s alpha $=0.72$ ), and these two scales were combined to create the total external knowledge measure.

To identify local team members, the survey asked: "Prior to the project, (a) how much time had you spent living in the client country? (years/months) (b) how much time had you spent working in the client country? (years/months) (c) did you speak local languages relevant to the project?” (yes or no). Similar questions were asked to identify cosmopolitan team members: “At the time that the project began, (a) how many countries had you lived in for 6 months or more? (b) how many countries had you worked in for 6 months or more? (c) how many languages did you speak competently?” The preliminary qualitative research confirmed that these characteristics were appropriate for identifying cosmopolitans and locals at Quorum. The interviews and observations further indicated that individuals who were high on all three characteristics of locals or cosmopolitans were most clearly recognizable as locals or cosmopolitans in their teams. Those who were high on some characteristics but not others, in contrast, were less clearly distinctive. I therefore adopted threshold standards for classifying an individual as a local or a cosmopolitan within the Quorum context. A team member qualified as a local if s/he had lived in the client country prior to the project and had worked in the client country prior to the project and spoke a local language (35\%, 56\%, and 58\% met the first, second, and third criteria). A team member qualified as a cosmopolitan if s/he had lived in 3 or more countries and had worked in 3 or more countries and spoke 3 or more languages. These requirements were empirically determined based on median splits of the sample (i.e., 50\% met each criterion). The threshold standards of meeting all three criteria simultaneously were strict to ensure that the empirical categories were consistent with the theoretical 
argument that locals and cosmopolitans can be viewed as categorically distinct from non-locals and noncosmopolitans. ${ }^{\text {vi }}$ Of the 485 team members in the study sample, 67 qualified as locals and 115 qualified as cosmopolitans, while the remainder qualified as neither locals nor cosmopolitans for the purposes of their team’s project. ${ }^{\text {vii }}$ Having classified the team members as locals, cosmopolitans, or others, I constructed team-level measures of the number of locals and the number of cosmopolitans on each team. To test for curvilinear relationships between the numbers of locals or cosmopolitans on a team and the dependent variables, I squared these measures after centering them. To test for the interaction effects predicted by Hypotheses 3a, 3b, 4a, and 4b, I multiplied each of the four measures by the internal knowledge and external knowledge measures, again after centering (Aiken and West 1991).

\section{Control Variables}

Additional variables that could be correlated with the dependent and independent variables were included in the models as controls. Two measures captured work experience at the time the project began: organizational tenure (average number of years the team members had been employed at Quorum) and non-organizational tenure (average number of years the team members had been employed in other organizations). The number of survey respondents and the number of survey non-respondents were included separately to control for team size while also capturing any effects due to missing data. ${ }^{\text {vii }}$ Also included were variables capturing the project duration (in years, logged), project cost (in dollars, logged), and project type (coded 1 for financial loan projects, 0 for technical analysis projects). ${ }^{\text {ix }}$

\section{RESULTS}

Descriptive statistics and correlations are reported in Table 1. Preliminary analysis of the sample characteristics indicated that the 96 project teams in the dataset ranged in size from 2 to 23 members, with an average of 8.5 members. $70 \%$ of the team members were based at the organization's U.S.

headquarters, $27 \%$ were based in the client country, and 3\% were based in other countries. $77 \%$ were fulltime employees of the organization and 23\% were external consultants. Team members spent an average of 16 months with their team, though their assignments ranged from less than a month to several years. 
They spent $30 \%$ of their time with that team on average, while simultaneously working on other projects with different teams. The same team members very rarely worked together across multiple projects - only 18 individuals of the 1021 surveyed appeared on more than one team roster. The average age of the survey respondents was 44 years, and 34\% were women. Cosmopolitans tended to be older than noncosmopolitans $(r=0.17, \mathrm{p}<0.01)$ and have longer organizational and non-organizational tenure $(\mathrm{r}=0.14$, $\mathrm{p}<0.01 ; \mathrm{r}=0.11, \mathrm{p}<0.01)$. Locals tended to be younger than non-locals ( $\mathrm{r}=-0.09, \mathrm{p}<0.10$ ), have shorter organizational tenure $(r=-0.23, p<0.01)$, and be based in the country office $(r=0.52, p<0.01)$. Team members who were neither cosmopolitans nor locals tended to be younger ( $r=-0.10, \mathrm{p}<0.10$ ), have shorter non-organizational tenure $(\mathrm{r}=-0.11, \mathrm{p}<0.10)$, and be based at Quorum's headquarters $(\mathrm{r}=0.35, \mathrm{p}<0.01)$.

\section{----- Insert Table 1 about here -----}

Before testing the hypotheses, I addressed the possibility of sampling bias in the dataset by comparing the 96 teams that qualified for inclusion in the study to the 24 disqualified teams using t-tests. The results indicated that the qualifying teams worked on more costly and lengthier projects, but there were no significant differences in their quality ratings, project type, region, or division. I also tested for the possibility of self-serving attribution bias by respondents who returned their surveys after their project's quality rating had been announced by comparing 19 teams whose members all returned their surveys before their ratings were determined to 37 teams whose members all returned their surveys afterwards. The t-tests revealed no differences on the variables that might be vulnerable to attribution bias, particularly the reported levels of internal knowledge and external knowledge. Correlations between the number who returned their surveys late and the reported levels of internal and external knowledge across all the teams were non-significant too. ${ }^{\mathrm{x}}$

\section{Internal Knowledge Acquisition Analyses (H1a/H1b)}

The upper section of Table 2 reports multivariate linear regression analyses conducted at the team level. To examine whether teams that included more locals and cosmopolitans had more internal knowledge, as predicted by H1a and H1b, the dependent variable in models 1-3 is the team's combined technical and country knowledge, while models 4-6 and models 7-9 break this composite variable into its 
technical and country knowledge components. The correlation between these components was fairly low $(\mathrm{r}=0.27, \mathrm{p}<0.01)$, supporting the value of examining them separately. The control variables (not shown) indicated that teams whose members had more years of non-organizational tenure had more internal knowledge, and teams that worked on financial loan projects had lower levels of internal knowledge than teams that worked on technical analysis projects. The results reported in the models reveal that teams with more locals had more internal knowledge (models 1 and 3), and this effect was driven by their higher levels of internal country knowledge in particular (models 7 and 9), as predicted in H1a. The results for H1b are surprising, however, since they indicate that teams with more cosmopolitans did not have more internal technical knowledge as predicted (models 5 and 6), but they did have more internal country knowledge before controlling for the number of locals (model 8). ${ }^{\mathrm{xi}}$

Because the team-level results could disguise the individual contributions of the different team members, the lower section of Table 2 reports additional multivariate analyses conducted at the individual level, where the dependent variable is the level of prior knowledge reported by an individual team member and the binary independent variables capture whether that team member was or was not a local or a cosmopolitan. These models used fixed effects to control for any unobserved heterogeneity between teams (Greene 1993), and also included controls (not shown) for organizational tenure (non-significant) and non-organizational tenure (positive and significant). The individual-level models shed considerable light on the team-level findings: they reveal that locals provided more internal country knowledge (model 8) while cosmopolitans provided more internal technical knowledge for their teams (model 6).

Taking the findings at the two levels of analysis together, the results reveal that locals provided more internal country knowledge as individuals, and this was reflected in higher levels of such knowledge in teams with more local members, providing strong support for H1a. Cosmopolitans provided more internal technical knowledge as individuals, consistent with H1b, but this contribution was not reflected in higher levels of such knowledge at the team level. Instead, teams with more cosmopolitans had higher levels of country knowledge before controlling for the number of locals on the team. A plausible explanation for these findings is that cosmopolitans were brought in to balance teams with large numbers 
of locals, which had high country knowledge but lacked sufficient technical knowledge. Cosmopolitans' strengths thus compensated for locals' shortcomings, though not enough to increase the average level of internal technical knowledge per team member.

----- Insert Table 2 about here -----

\section{External Knowledge Acquisition Analyses (H2a/H2b)}

Table 3 reports the team-level and individual-level models for H2a and H2b, which predicted that teams with more locals gather more external country knowledge and teams with more cosmopolitans gather more external technical knowledge. The team-level models indicated no significant effects of any of the control variables (not shown). The upper section of the table reveals that teams with more locals gathered more external knowledge overall before controlling for the number of cosmopolitans (model 1), and teams with more cosmopolitans gathered more external knowledge overall before and after controlling for the number of locals (models 2 and 3). The results are similar for technical and country knowledge (models 4-6 and 7-9). Although contrary to the predicted differences across the two knowledge types, this similarity is not surprising given a high correlation between these variables ( $\mathrm{r}=0.77$, $\mathrm{p}<0.01)$. Further analysis at the individual level, reported in the lower section of the table, again offers more insight into the team-level findings, by revealing that cosmopolitans gathered more external knowledge as individuals but locals did not.

Taken together, these results do not support H2a, since locals did not gather more country knowledge for their teams, and teams with more locals did not gather more external country knowledge after accounting for the contributions of their cosmopolitan members. In contrast, teams with more cosmopolitans did gather more technical knowledge, as predicted by H2b, and these knowledge acquisition benefits were due to the cosmopolitans themselves. In addition, the results indicate that teams with more cosmopolitans also gathered more country knowledge due to their own efforts, a result that could be explained by a wish to compensate for any weaknesses of their own in that area or by a tendency for survey respondents to answer questions concerning technical and country knowledge similarly. 


\section{Internal and External Knowledge Application Analyses (H3a/H3b and H4a/H4b)}

Table 4 and Table 5 present the ordinal logit analyses for H3a/H3b and H4a /H4b respectively, where the dependent variable is the quality of the project delivered by the team. These models included the full set of control variables (not shown): the only significant effects were a positive association between project quality and the number of team members who responded to the survey and a negative association between project quality and the number of team members who did not respond to the survey. Additionally, the internal knowledge models controlled for external knowledge, and the external knowledge models controlled for internal knowledge, but these controls were not significant in any of the models. As shown, the main effects of internal knowledge also were not significant in Table 4, and only the main effects of external country knowledge were significant in Table 5. This lack of main or mediating effects of the knowledge variables indicates that locals and cosmopolitans did not improve project quality directly by providing more internal knowledge or gathering more external knowledge for the team. Instead, the models reveal that local and cosmopolitan team members served to moderate the effects of internal and external knowledge on project quality.

----- Insert Table 4 and Table 5 about here -----

Models 1-3 in Table 4 focus on how local and cosmopolitan members affected the relationship between the team's total internal knowledge and the quality of its project. There is some evidence of a marginally significant interaction between total internal knowledge and the number of locals (model 1) as well as the number of cosmopolitans (model 2). Both of these interaction effects are negative, however, rather than positive as predicted in H3a and H3b. Further exploration of these interactions by separating technical knowledge (in models 4-6) from country knowledge (in models 7-9) reveals that the negative interaction for locals is driven by the technical knowledge component, while the negative interaction for cosmopolitans is driven by the country knowledge component. Rather than helping their teams to apply their internal country and technical knowledge more effectively, as predicted by H3a and H3b, locals and cosmopolitans thus impeded exploitation of knowledge that did not correspond to their respective strengths. 
Table 5 reports the models that show how local and cosmopolitan members affected the relationship between the team's level of external knowledge gathering and the quality of its project. In these models, unlike the preceding ones, curvilinear effects are seen when the second-order local and cosmopolitan terms are included. Results for technical and country knowledge are not reported separately given their high correlation; the results for each are similar to the results for the total external knowledge measure. Models 1-6 show few main effects for the first or second-order local and cosmopolitan terms, but the subsequent models show that there are interaction effects with external knowledge. Model 9, where locals and cosmopolitans are considered together, shows that the relationship between external knowledge gathering and project quality is more negative for teams that include more locals. This contradicts H4a, which predicted a positive interaction effect. In contrast, the relationship is more positive for teams that include more cosmopolitans, supporting H4b. However, these first-order interaction effect results indicate only the average effects of having more locals or cosmopolitans on the team, and as models 10-12 show, the full results are more complex. To facilitate interpretation of the second-order interaction effects, the results from models 10 and 11 are plotted separately in Figure 2.

----- Insert Figure 2 about here -----

Figure 2(a) shows that at all levels of external knowledge, teams that had low numbers of locals delivered higher quality projects than teams that had high numbers of locals. This general pattern reflects the average negative interaction effect for locals. Teams with very low numbers of locals performed worse than teams with low numbers of locals or high numbers of locals, however, at higher levels of external knowledge (above 3.8 and 4.0, respectively) - although they performed better than teams with very high numbers of locals at all levels of external knowledge. In summary, the plot indicates that higher numbers of locals generally were harmful, though low numbers sometimes were better than very low numbers. H4a therefore is only supported when the number of locals on the team is low.

Figure 2(b) shows that teams performed better if they had high numbers of cosmopolitans than if they had low numbers of cosmopolitans at moderate to high levels of external knowledge (above 2.5), reflecting the average positive interaction effect for cosmopolitans. Teams with very high numbers of 
cosmopolitans performed worse than teams with high numbers of cosmopolitans or low numbers of cosmopolitans, however, at higher levels of external knowledge (above 3.6 and 4.3, respectively). Additionally, teams performed better if they had low rather than high numbers of cosmopolitans at low levels of external knowledge (below 2.5). This plot thus indicates that higher numbers of cosmopolitans generally increased the benefits of external knowledge for project quality, as predicted by H4b, but very high numbers were harmful, and low numbers were preferable at low levels of external knowledge.

\section{DISCUSSION}

The findings of this study reveal that the roles of locals and cosmopolitans in facilitating the acquisition and application of internal and external knowledge in transnational teams are complex and sometimes unexpected. Considering internal knowledge first, the results showed that both locals and cosmopolitans helped their teams to acquire more internal knowledge. Locals brought prior country knowledge with them when they joined the team and thus increased the internal country knowledge available to the team. Cosmopolitans brought prior technical knowledge with them when they joined the team, although the average level of internal technical knowledge per team member did not increase accordingly, possibly because the cosmopolitans were brought in to compensate for shortfalls in the technical knowledge of locals or other team members. Surprisingly, teams that had higher levels of internal knowledge did not necessarily deliver higher quality projects, and neither locals nor cosmopolitans enabled their teams to transform internal knowledge into higher quality projects more successfully. Instead, locals and cosmopolitans could hurt team performance when the internal knowledge applied to the project was inconsistent with their expertise: the more locals on a team, the more negative the relationship between technical knowledge and project quality, and the more cosmopolitans on a team, the more negative the relationship between country knowledge and project quality.

Considering external knowledge, the roles of locals were even less beneficial, although cosmopolitans offered some benefits to their teams. Individual locals did not gather more external country knowledge than non-locals, and teams with more local members did not gather more external country 
knowledge after controlling for the number of cosmopolitans on the team. In contrast, individual cosmopolitans did gather more technical knowledge than non-cosmopolitans, and teams with more cosmopolitan members gathered more technical knowledge. Cosmopolitans thus facilitated external knowledge acquisition, but locals did not. More external knowledge did not necessarily result in higher quality projects, though; the effects of external knowledge on project quality instead depended on the numbers of locals and cosmopolitans on the team in complex ways. On average, the more locals a team included, the more negative the relationship between the amount of external knowledge gathered and project quality, whereas the more cosmopolitans a team included, the more positive this relationship. Low numbers of locals were beneficial, however, and very high numbers of cosmopolitans could hurt.

In summary, these complex findings reveal that locals and cosmopolitans have diverse and important roles to play in transnational teams. Taken together, the findings suggest that in the setting where the research was conducted, an ideal team composition included one or two local members, but not more, and several cosmopolitans, but not too many. The roles played by both locals and cosmopolitans were valuable in that some of each were helpful, but asymmetrical in that more cosmopolitans offered greater benefits than more locals. This could be due to greater redundancy among locals with overlapping experiences living and working in the client country, compared to cosmopolitans with diverse experiences living and working in different countries. The roles of both locals and cosmopolitans were also limited as additional locals or cosmopolitans did not always incrementally facilitate knowledge acquisition and application, and sometimes they were even harmful as too many locals or cosmopolitans could impede effective knowledge application. Consistent with prior research on group composition (e.g., Janis 1982), the findings therefore suggest that a mix of local, cosmopolitan, and other team members is important in avoiding the potential biases or blind spots that may arise if transnational teams are excessively dominated by too many like-minded individuals.

\section{Implications for Theory and Research}

In examining the cosmopolitan and local composition of transnational teams, this study extends international management theory and research by linking the macro strategic and structural imperatives 
facing transnational organizations to their micro structures and processes. Scholars have long recognized that transnational organizations face a strategic mandate to "think globally, act locally", and that this calls for an organizational structure that combines global integration with local differentiation among subsidiaries (Bartlett and Ghoshal 1989; Birkinshaw and Morrison 1995). The knowledge-based view of the firm advances these ideas by recasting the strategic mandate in terms of the need to share knowledge globally and customize it locally, and highlighting a structural imperative to establish formal and informal mechanisms that encourage rather than inhibit worldwide learning (Grant 1996; Kogut and Zander, 1993). Central to this emerging view of the knowledge-based transnational are the structures and processes of the task units that conduct the daily work of the organization, which are often project teams. This paper demonstrates the importance of one set of structural conditions, the local and cosmopolitan composition of these teams, by linking them to one set of critical team processes, the acquisition and application of knowledge. The intersections between other micro structures and processes, such as individual versus group rewards and knowledge sharing for example, offer promising directions for future research.

Recognizing the value of the local/cosmopolitan distinction in understanding knowledge acquisition and application in the transnational context also offers implications for theory about virtual teams. Research on issues such as the need for face-to-face meetings, cross-cultural communication, and trust formation in virtual teams could be reinterpreted in light of the study findings. For example, given that locals and cosmopolitans have such different knowledge orientations, identifying ways to span the boundaries between them might reduce the need for face-to-face meetings, perhaps through the use of “boundary objects” such as a standardized memo templates for capturing and presenting local and cosmopolitan views on the same issue (cf. Carlile 2002). Highlighting the knowledge orientations of locals and cosmopolitans also raises the possibility that there might be other knowledge-related orientations worthy of consideration in virtual team research. Perhaps team members who have more extensive experience with virtual work tend to assume leadership or coaching roles, for example, while those who have less experience with virtual work assume secondary or learning roles in their teams. 
Beyond the transnational context, prior team studies have directly and indirectly addressed the learning processes of exploitation and exploration in ways that are potentially complementary, yet rarely integrated. For example, research relevant to exploitation has been conducted by group scholars who study knowledge utilization within teams, looking at issues ranging from expertise diversity (e.g., Bunderson and Sutcliffe 2002) to transactive memory systems (e.g., Liang et al. 1995, Lewis et al. 2005), while exploration has been examined by researchers who study boundary-spanning behaviors (e.g., Ancona and Caldwell 1992) as well as knowledge sharing networks (e.g., Hansen 1999; Reagans and McEvily 2003). One reason for the lack of integration in these approaches is that scholars who take an internal perspective on teams often use laboratory methods whereas those who take an external perspective usually conduct field research (Ancona 1993); another is that exploitation and exploration are often viewed as alternative rather than complementary priorities for organizations (Benner and Tushman 2003). Yet these processes are closely intertwined for many project teams in contemporary knowledgeintensive organizations, since the work requires both exploration and exploitation. This study takes one approach to recognizing that reality by considering the acquisition and application of both internal and external knowledge within a shared framework and examining the different roles that the same team members play across different elements of the exploration and exploitation processes.

Highlighting the roles of cosmopolitan and local team members also contributes to the organizational knowledge and learning literatures by showing that human capital characteristics can facilitate or impede knowledge acquisition and application. Prior theory and research has focused primarily on the characteristics of the knowledge itself or the channels through which it is shared. For example, knowledge is more difficult to transfer if it is more tacit or causally ambiguous (Szulanski 1996; Zander and Kogut 1995), while codified knowledge is transferred more effectively if document databases use appropriate publishing strategies to attract attention (Hansen and Haas 2001). In contrast to such prior studies, this paper focuses attention on the levels and types of experience of the individuals who acquire and apply knowledge. Future examination of possible intersections between these approaches could offer further insights: for example, the roles of cosmopolitans and locals might be particularly valuable when 
the team must acquire and apply knowledge that is more tacit or complex. This study also extends prior research by moving beyond the assumption that simply having more internal knowledge or gathering more external knowledge will necessarily result in improved performance. Indeed, the findings revealed no main effects of higher levels of internal or external knowledge on project quality. However, more knowledge did improve performance when the local and cosmopolitan composition of the team was appropriate - and hurt when it was not. Rather than assuming that more knowledge is better, the study thus offers insight into the conditions under which the much vaunted but often elusive value of knowledge is most likely to be claimed (see also Haas 2006; Haas and Hansen 2005).

\section{Limitations and Future Directions}

The empirical research focused on a single organization where projects were carried out by teams that included some members with very broad global experience and some with deep local experience, as well as others whose global and local experience was less extensive. Such team members may not be common in all transnational organizations, however, as the nature of project work and team structures vary considerably. While the contribution of this study lies in demonstrating the usefulness of the concepts of cosmopolitans and locals for understanding knowledge acquisition and application in project teams, the specific levels of global and local experience that distinguish cosmopolitans and locals also may vary across organizations, and their strengths and weaknesses may vary too. Understanding of their roles also could be enriched by examining the simultaneous effects of functional, national, cultural, and locational diversity, as well as the internal dynamics of status contests, conflicts, and competition for influence that may arise within teams that include cosmopolitans and local members (e.g., Haas 2005). Additionally, this study did not directly examine the extent to which knowledge was transferred and shared among team members with different knowledge orientations, but prior research suggests that this can affect individual and collective learning and performance (e.g., Liang et al. 1995; Bunderson and Sutcliffe 2002; Lewis et al. 2005). Lack of knowledge transfer or shared mental models in teams with cosmopolitan and local members might even help to explain why the teams in this study did not always benefit as much as might be expected from such members. 
This study identified individuals as either locals or non-locals and as either cosmopolitans or noncosmopolitans. This binary classification approach was used because it is consistent with the prior theoretical literature, which conceptualizes locals and cosmopolitans as categories of individuals who have associated roles to play in their communities (Merton 1957; Kanter 1995) or organizations (Gouldner 1957; Tung 1998). Locals and cosmopolitans were identified using theoretically and empirically derived standards based on meeting multiple identifying criteria simultaneously. However, alternative approaches are possible and worthy of consideration. One alternative would be to use statistically-based methods to categorize team members by the extent to which they share a set of characteristics. Exploratory classifications revealed that techniques such as factor and cluster analysis required their own judgment calls, however, and the resulting categories sometimes were difficult to defend substantively, as some individuals classified as locals did not speak the local language, for example, while others classified as cosmopolitans had lived in only one country. Another alternative might be to focus on the overall level of "localism” or "cosmopolitanism” on a team by combining the identifying criteria into continuous indices. Yet this approach overlooks the precedents in the prior theoretical literature by moving away from a categorical conceptualization of locals and cosmopolitans, and also requires its own assumptions about how to weight the constituent elements of the indices. Exploratory analyses using such indices revealed few interesting results, moreover, further supporting the premise that the presence of individuals who play local or cosmopolitan roles on their teams matters more than levels of localism or cosmopolitanism. Nevertheless, further investigation of alternative classification approaches could further advance understanding of the roles of locals and cosmopolitans in transnational teams.

More ambitiously, while this paper has focused on transnational teams and organizations, a broader application of the concepts of cosmopolitans and locals might be possible. The early sociological theories that first introduced these concepts did not anchor them in an international context (Gouldner 1957; Merton 1957). It would be consistent with these early theories to view the categories of cosmopolitans and locals not just as narrowly distinguishing those with broad cross-country experience 
from those with deep country-specific experience, but as more generally distinguishing individuals with broad experience that is not context-specific from individuals with deep context-specific experience. By generalizing the concepts in this way, they might advance our understanding of experts and expertise utilization in teams that are not transnational too, and provide insight into the processes and outcomes of knowledge acquisition and application in non-international as well as international domains.

Finally, this study focused on a particular type of work where the acquisition and application of knowledge is central to team and organization performance. External knowledge gathering was not just the responsibility of one or two team members at Quorum; instead, nearly all team members reported gathering at least some external knowledge because each component of their complex projects demanded more knowledge than even the most expert teams possessed. Where work is labor-intensive or capitalintensive rather than knowledge-intensive, however, inputs other than knowledge are more important (Starbuck 1992), raising questions about the roles of cosmopolitans and locals in such contexts. Further questions concern work outcomes other than the project quality outcomes examined here. Even in knowledge-intensive work settings where cosmopolitans and locals help their teams to deliver higher quality projects, these individuals may not help their organizations to ultimately translate their knowledge resources into superior competitive performance, due to other factors that offset the benefits of project quality such as imitation or innovation by competitors (cf. Coff et al. 2005). The precise nature, extent, and limits of the array of potential contributions of cosmopolitan and local team members thus open up many research avenues worthy of future exploration.

In conclusion, transnational organizations that are project-driven, team-based, and focused on worldwide learning face challenges of knowledge acquisition and application that can critically affect their performance. Cosmopolitans and locals can facilitate these processes and help their teams and organizations perform more successfully, but their roles and contributions are complex, often subtle, and sometimes harmful rather than helpful. 


\section{REFERENCES}

Ai, C., E.C. Norton. 2003. Interaction terms in logit and probit models. Economics Letters, 80: 123-129.

Aiken, L.S., S.G. West. 1991. Multiple Regression: Testing and Interpreting Interactions. Newbury Park, CA: Sage.

Ancona, D.G., D.F. Caldwell. 1992. Bridging the boundary: External activity and performance in organizational teams. Administrative Science Quarterly, 37: 634-665.

Ancona, D.G. 1993. The classics and the contemporary: A new blend of small group theory. In J.K. Murninghan (ed.), Social Psychology in Organizations: Advances in Theory and Research: 225-243. Englewood Cliffs, NJ: Prentice Hall.

Athanassiou, N., D. Nigh. 2000. Internationalization, tacit knowledge, and the top management teams of MNCs. Journal of International Business Studies, 31: 471-487.

Bae, J., J.J. Lawler. 2000. Organizational and HRM strategies in Korea: Impact on firm performance in an emerging economy. Academy of Management Journal, 43: 502-519.

Baruch, Y., Y. Altman. 2002. Expatriation and repatriation in MNCs: A taxonomy. Human Resource Management, 41: 239-259.

Bartlett, C.A., S. Ghoshal. 1989. Managing Across Borders: The Transnational Solution. Boston: HBS Press.

Belderbos, R.A., M.G. Heijltjes. 2005. The determinants of expatriation in Japanese multinationals: Network ties and executive staffing policies in Asia. Journal of International Business Studies, forthcoming.

Benner, M.J, M. L. Tushman. 2003. Exploitation, exploration, and process management: The productivity dilemma revisited. Academy of Management Review, 28: 238-256.

Bhagat, R.S., B.L. Kedia, P.D. Harveston, H.C. Triandis. 2002. Cultural variations in cross-border transfer of organizational knowledge: An integrative framework. Academy of Management Review, 27: 204-221.

Birkinshaw, J.M., A.J. Morrison. 1995. Configurations of strategy and structure in subsidiaries of multinational corporations. Journal of International Business Studies, 26: 729-754.

Bjorkman, I. W. Barner-Rasmussen, L. Li. 2004. Managing knowledge transfer in MNCs: The impact of headquarters control mechanisms. Journal of International Business Studies, 35: 443-455.

Bunderson, J.S., K.M. Sutcliffe. 2002. Comparing alternative conceptualizations of functional diversity in management teams: Process and performance effects. Academy of Management Journal, 45: 875-893.

Carlile, P.R. 2002. A pragmatic view of knowledge and boundaries. Organization Science, 13: 442-455.

Coff, R., D. Coff, R. Eastvold. 2005. The knowledge leveraging paradox: How to scale up without making knowledge imitable. Forthcoming in Academy of Management Review.

Cummings, J.N. 2004. Work groups, structural diversity, and knowledge sharing in a global organization. Management Science, 50: 352-364.

Earley, P.C., E. Mosakowski. 2000. Creating hybrid team cultures: An empirical test of transnational team functioning. Academy of Management Journal, 43: 26-49. 
Edstrom A., J. R. Galbraith. 1977. Transfer of managers as a coordination and control strategy in multinational organizations. Administrative Science Quarterly, 22: 248-263.

Elron, E. 1997. Top management teams within multinational corporations: Effects of cultural heterogeneity. Leadership Quarterly, 8: 393-412.

Gibson, C.B., S.B. Cohen. 2003. Virtual Teams That Work: Creating Conditions For Virtual Team Effectiveness. San Francisco, CA: Jossey-Bass.

Gouldner, A.W. 1957. Cosmopolitans and locals: Toward an analysis of latent social roles - I. Administrative Science Quarterly, 281-306.

Greene, W.H. 1993. Econometric Analysis. Second Edition. New York: Macmillan.

Grant, R.M. 1996. Prospering in dynamically competitive environments: Organizational capability as knowledge integration. Organization Science, 7: 375-387.

Gupta, A.K., V. Govindarajan. 2000. Knowledge flows within multinational corporations. Strategic Management Journal, 21: 473-496.

Haas, M.R. 2005. Cosmopolitans and locals: Status rivalries, deference, and knowledge in international teams. In M.C. Thomas-Hunt, E.A. Mannix, M.A. Neale (eds.), Research on Managing Groups and Teams: Status and Groups, 7: 201-227. Oxford, U.K.: Elsevier.

Haas, M.R. 2006. Knowledge gathering, team capabilities, and project performance in challenging work environments. Management Science, forthcoming.

Haas, M.R., M.T. Hansen. 2005. When using knowledge can hurt performance: The value of organizational capabilities in a management consulting firm. Strategic Management Journal, 26: 1-24.

Hackman, J.R. 2002. Leading Teams: Setting the Stage for Great Performances. Boston: HBS Press.

Hambrick, D.C., S.C. Davison, S.A. Snell, C.C. Snow. 1998. When groups consist of multiple nationalities: Towards a new understanding of the implications. Organization Studies, 19: 181-205.

Hansen, M.T. 1999. The search-transfer problem: The role of weak ties in sharing knowledge across organization subunits. Administrative Science Quarterly, 44: 82-111.

Hansen, M.T., M.R. Haas. 2001. Competing for Attention in Knowledge Markets: Electronic Document Dissemination in a Management Consulting Company. Administrative Science Quarterly, 46: 1-28.

Hinds, P., S. Kiesler. 1995. Communication across boundaries: Work, structure, and communication technologies in a large organization. Organization Science, 6: 373-294.

Hocking, J.B., M. Brown, A.Harzing. 2004. A knowledge transfer perspective of strategic assignment purposes and their path-dependent outcomes. Journal of Human Resource Management, 15: 565-586.

Hofstede, G. 1980. Culture's Consequences. International Differences in Work-Related Values. Beverly Hills, CA: Sage.

Huber, G.P. 1991. Organizational learning: The contributing processes and literatures. Organization Science, 2: 88-115. 
Jackson, S.E., M.A. Hitt, A.S. DeNisi, eds. 2003. Knowledge for Sustained Competitive Advantage: Designing Strategies for Effective Human Resource Management. San Francisco, CA: Jossey-Bass.

Janis, I.L. 1982. Groupthink (2 ${ }^{\text {nd }}$ ed.). Boston: Houghton Mifflin.

Jarvenpaa, S.L., D.E. Leidner. 1999. Communication and trust in global virtual teams. Organization Science, 19: 791-815.

Kanter, R.M. 1995. World Class: Thriving Locally in the Global Economy. New York: Simon and Schuster.

Kirkman, B.L., C.B. Gibson, D.L. Shapiro. 2001. "Exporting” teams: Enhancing the implementation and effectiveness of work teams in global affairs. Organizational Dynamics, 30: 12-29.

Kirkman, B.L., D.L. Shapiro. 1997. The impact of cultural values on employee resistance to teams:

Toward a model of globalized self-managing work team effectiveness. Academy of Management Review, 22: 730-757.

Kogut, B., U. Zander. 1992. Knowledge of the firm, combinative capabilities, and the replication of technology. Organization Science, 3 : 383-397.

Kogut, B., U. Zander. 1993. Knowledge of the firm and the evolutionary theory of the multinational. Journal of International Business Studies, 24 : 625-645.

Lau, D.C., Murninghan, J.K. 1998. Demographic diversity and faultlines: The compositional dynamics of organizational groups. Academy of Management Review, 23: 325-340.

Levin, D., R. Cross. 2004. The strength of weak ties you can trust: The mediating role of trust in effective knowledge transfer. Management Science, 50: 1477-1490.

Lewis, K., D. Lange, L. Gillis. 2005. Transactive memory systems, learning, and learning transfer. Organization Science, 16: 581-596.

Liang, D.W., R.L. Moreland, L. Argote. 1995. Group versus individual training and group performance: The mediating role of transactive memory. Personality and Social Psychology Bulletin, 21: 384-393.

Long, J.S. 1997. Regression Models for Categorical and Limited Dependent Variables. Newbury Park, CA: Sage.

Lord, M.D., A.L. Ranft. 2000. Organizational learning about new international markets: Exploring the internal transfer of local market knowledge. Journal of International Business Studies, 31: 573-589.

Lyles, M.A., J.E. Salk. 1996. Knowledge acquisition from foreign parents in international joint ventures: An empirical examination in the Hungarian context. Journal of International Business Studies, 27: 877-903.

Majchrzak, A., L.P. Cooper, O.E. Neece. 2004. Knowledge reuse for innovation. Management Science, 50: 174-189.

Makino, S., A. Delios. 1996. Local knowledge transfer and performance: Implications for alliance formation in Asia. Journal of International Business Studies, 30: 905-927.

March, J.G. 1991. Exploration and exploitation in organizational learning. Organization Science, 2: 71-87.

Markus, H. S. Kitayama. 1991. Culture and self: Implications for cognition, emotion, and motivation.

Psychological Review, 98: 224-253. 
Maznevski, M., C. Chudoba. 2000. Bridging space over time: Global virtual team dynamics and effectiveness. Organization Science, 11: 473-492.

Mendenhall, M., G. Oddou. 1986. Acculturation profiles of expatriate managers: Implications for crosscultural training programs. Columbia Journal of World Business, 73: 21-28.

McEvily, B., V. Perrone, A. Zaheer. 2003. Trust as an organizing principle. Organization Science, 14: 91-103.

Menon, T., J. Pfeffer. 2003. Valuing internal versus external knowledge: Explaining the preference for outsiders. Management Science, 49: 497-514.

Merton, R.K. 1957. Social Theory and Social Structure ( $2^{\text {nd }}$ ed.). Glencoe, IL: Free Press.

Mohrman, S.A., S.G. Cohen, A.M. Mohrman. 1995. Designing Team-Based Organizations: New Forms for Knowledge Work. San Francisco: Jossey-Bass.

Nohria, N., S. Ghoshal. 1997. The Differentiated Network: Organizing Multinational Corporations for Value Creation. San Francisco: Jossey-Bass.

Obstfeld, D. 2005. Social networks, the tertius iungens orientation, and involvement in innovation. Administrative Science Quarterly, 50: 100-130.

Ralston, D. A.., Y. Kai-Cheng, X. Wang, R. Terpstra, H. We. 1996. The cosmopolitan Chinese manager: Findings of a study on managerial values across the six regions of China. Journal of International Management, 2: 79-109.

Reagans, R., B. McEvily. 2003. Network structure and knowledge transfer: The effects of cohesion and range. Administrative Science Quarterly, 48: 240-267.

Snow, C.C., S.A. Snell, S.C. Davison, D.C. Hambrick. 1996. Use transnational teams to globalize your company. Organizational Dynamics, 32(4): 20-32.

Starbuck, W.H. 1992. Learning by knowledge-intensive firms. Journal of Management Studies, 29: 713-741.

Sutton, R. I., A. Hargadon. 1996. Brainstorming groups in context: Effectiveness in a product design firm. Administrative Science Quarterly, 41: 685-718.

Swidler, A. 1986. Culture in action: Symbols and strategies. American Sociological Review, 51: 273-286.

Szulanski, G. 1996. Exploring internal stickiness: Impediments to the transfer of best practice within the firm. Strategic Management Journal, 17: 27-43.

Thomas, J.B., S.W. Sussman, J.C. Henderson. 2001. Understanding “strategic learning”: Linking organizational learning, knowledge management, and sensemaking. Organization Science, 12: 331-345.

Triandis, H.C. 1989. The self and social behavior in differing cultural contexts. Psychological Review, 96: 269-289.

Tsai, W.P. 2001. Knowledge transfer in intraorganizational networks: Effects of network position and absorptive capacity on business unit innovation and performance. Academy of Management Journal, 44: 996-1004.

Tsang, E.W.K. 2001. Managerial learning in foreign-invested enterprises of China. Management International Review, 41: 29-51. 
Tung, R. 1987. Expatriate assignments: Enhancing success and managing failure. Academy of Management Executive, 1: 117-127.

Tung, R. 1998. American expatriates abroad: From neophytes to cosmopolitans. Journal of World Business, 33: 125-144.

Zahra, S.A., G. George. Absorptive capacity: A review, reconceptualization, and extension. Academy of Management Review, 27: 185-203.

Zander, U., B. Kogut. 1995. Knowledge and the speed of transfer and imitation of organizational capabilities: An empirical test. Organization Science, 6: 76-92 
FIGURE 1. Theoretical Framework

\begin{tabular}{|c|c|c|}
\hline & $\begin{array}{c}\text { Internal } \\
\text { Knowledge }\end{array}$ & $\begin{array}{c}\text { External } \\
\text { Knowledge }\end{array}$ \\
\hline $\begin{array}{l}\text { Knowledge } \\
\text { Acquisition }\end{array}$ & H1a/H1b & $\mathrm{H} 2 \mathrm{a} / \mathrm{H} 2 \mathrm{~b}$ \\
\hline $\begin{array}{l}\text { Knowledge } \\
\text { Application }\end{array}$ & H3a/H3b & $\mathrm{H} 4 \mathrm{a} / \mathrm{H} 4 \mathrm{~b}$ \\
\hline
\end{tabular}

\section{FIGURE 2. Moderating Effects of Locals and Cosmopolitans on Relationship between External Knowledge Gathering and Project Quality (H4a/H4b)}

(a)

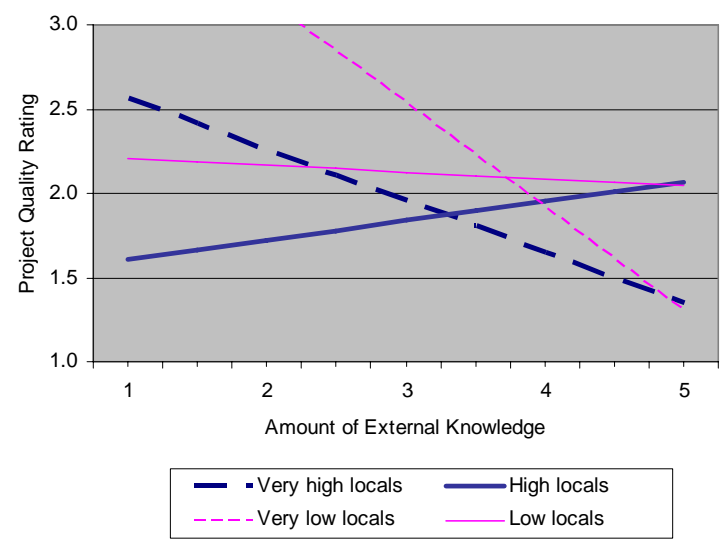

(b)

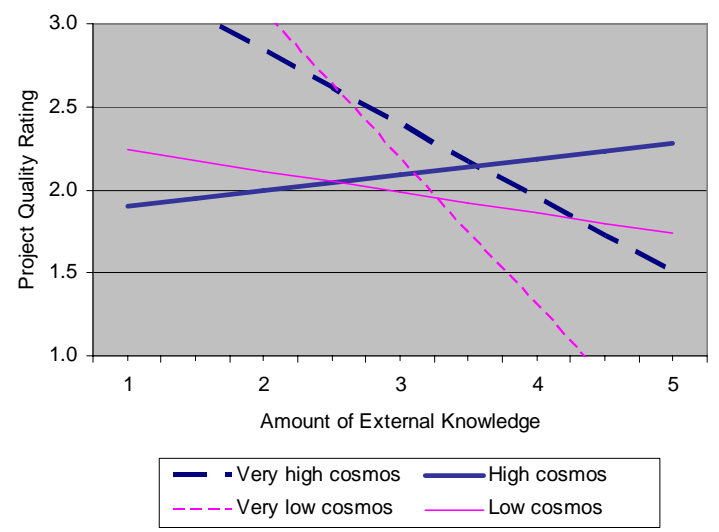

Note: The plots were constructed using OLS regression, with high numbers of locals or cosmopolitans are set at one standard deviation above or below the mean, very high numbers of locals or cosmopolitans are set at two standard deviations above or below the mean, and all other variables held constant at their means.

TABLE 1. Descriptive Statistics and Bivariate Correlations $(\mathbf{n}=96)^{1}$

\begin{tabular}{|c|c|c|c|c|c|c|c|c|c|c|c|c|c|c|c|}
\hline Variable & Mean & S.D. & Min & Max & 1 & 2 & 3 & 4 & 5 & 6 & 7 & 8 & 9 & 10 & 11 \\
\hline 1. Project quality & 2.02 & 0.54 & 1.00 & 3.00 & & & & & & & & & & & \\
\hline 2. Internal knowledge & 3.62 & 0.54 & 2.00 & 4.60 & .07 & & & & & & & & & & \\
\hline 3. External knowledge & 3.00 & 0.43 & 1.91 & 3.98 & .10 & .19 & & & & & & & & & \\
\hline 4. Organizational tenure & 8.46 & 4.40 & 1.00 & 25.50 & .09 & .00 & -.02 & & & & & & & & \\
\hline 5. Non-organizational tenure & 16.93 & 7.05 & 2.50 & 36.50 & -.03 & .31 & .05 & -.05 & & & & & & & \\
\hline 6. Team size (respondents) & 5.05 & 2.49 & 2.00 & 13.00 & .31 & .03 & .06 & -.12 & .15 & & & & & & \\
\hline 7. Team size (non-respondents) & 3.43 & 2.52 & 0.00 & 14.00 & -.08 & -.09 & .05 & -.09 & .17 & .37 & & & & & \\
\hline 8. Project cost $(\log )$ & 5.42 & 0.92 & 3.00 & 7.62 & -.01 & .06 & -.01 & -.11 & .32 & .38 & .36 & & & & \\
\hline 9. Project duration (log) & 5.61 & 0.75 & 3.76 & 7.27 & -.10 & .03 & -.02 & -.14 & -.03 & -.02 & .02 & .21 & & & \\
\hline 10. Project type & 0.52 & 0.50 & 0.00 & 1.00 & .08 & -.10 & .00 & .12 & .35 & .31 & .16 & .20 & -.17 & & \\
\hline 11. No. of Locals & 0.96 & 1.09 & 0.00 & 5.00 & .13 & .22 & .19 & -.27 & .05 & .53 & -.09 & .18 & -.03 & .14 & \\
\hline 12. No. of Cosmopolitans & 1.46 & 1.27 & 0.00 & 6.00 & .23 & .12 & .25 & .01 & .14 & .63 & .27 & .35 & .02 & .15 & .46 \\
\hline
\end{tabular}

\footnotetext{
${ }^{1}$ Values over 0.21 are significant at $p<0.05$
} 
TABLE 2. Results of Team-Level and Individual-Level Regression Analysis for H1a/H1b, DV=Internal Knowledge

\begin{tabular}{|c|c|c|c|c|c|c|c|c|c|}
\hline & \multicolumn{3}{|c|}{$\begin{array}{c}\text { Total Internal Knowledge } \\
\text { (Team Level) }\end{array}$} & \multicolumn{3}{|c|}{$\begin{array}{l}\text { Internal Technical Knowledge } \\
\text { (Team Level) }\end{array}$} & \multicolumn{3}{|c|}{$\begin{array}{c}\text { Internal Country Knowledge } \\
\text { (Team Level) }\end{array}$} \\
\hline & Model 1 & Model 2 & Model 3 & Model 4 & Model 5 & Model 6 & Model 7 & Model 8 & Model 9 \\
\hline Constant & $\begin{array}{l}3.03 \cdot \bullet \bullet \\
(0.48)\end{array}$ & $\begin{array}{c}3.23 \bullet \bullet \bullet \\
(0.50)\end{array}$ & $\begin{array}{c}3.07 \bullet \bullet \bullet \\
(0.49)\end{array}$ & $\begin{array}{l}3.52 \bullet \bullet \\
(0.58)\end{array}$ & $\begin{array}{c}3.51 \bullet \bullet \\
(0.58)\end{array}$ & $\begin{array}{l}3.40 \cdot \bullet \\
(0.62)\end{array}$ & $\begin{array}{l}2.56 \bullet \bullet \bullet \\
(0.67)\end{array}$ & $\begin{array}{c}2.99 \cdot \bullet \bullet \\
(0.69)\end{array}$ & $\begin{array}{l}2.76 \bullet \bullet \bullet \\
(0.68)\end{array}$ \\
\hline No. of Locals & $\begin{array}{l}0.17 \bullet \bullet \\
(0.06)\end{array}$ & & $\begin{array}{l}0.16 \bullet \\
(0.06)\end{array}$ & $\begin{array}{l}0.07 \\
(0.07)\end{array}$ & & $\begin{array}{c}0.09 \\
(0.08)\end{array}$ & $\begin{array}{l}0.26 \bullet \bullet \\
(0.09)\end{array}$ & & $\begin{array}{l}0.23 \bullet \bullet \\
(0.09)\end{array}$ \\
\hline No. of Cosmopolitans & & $\begin{array}{c}0.06 \\
(0.05)\end{array}$ & $\begin{array}{c}0.02 \\
(0.05)\end{array}$ & & $\begin{array}{l}-0.05 \\
(0.06)\end{array}$ & $\begin{array}{l}-0.07 \\
(0.06)\end{array}$ & & $\begin{array}{l}0.17 \bullet \\
(0.07)\end{array}$ & $\begin{array}{c}0.12 \\
(0.07)\end{array}$ \\
\hline \multirow{4}{*}{$\begin{array}{l}\text { Degrees of freedom } \\
\text { R-squared } \\
\mathrm{N}=96\end{array}$} & 8 & 8 & 9 & 8 & 8 & 9 & 8 & 8 & 9 \\
\hline & 0.26 & 0.20 & 0.26 & 0.13 & 0.13 & 0.14 & 0.25 & 0.21 & 0.27 \\
\hline & \multicolumn{3}{|c|}{$\begin{array}{l}\text { Total Internal Knowledge } \\
\text { (Individual Level) }\end{array}$} & \multicolumn{3}{|c|}{$\begin{array}{l}\text { Internal Technical Knowledge } \\
\text { (Individual Level) }\end{array}$} & \multicolumn{3}{|c|}{$\begin{array}{l}\text { Internal Country Knowledge } \\
\text { (Individual Level) }\end{array}$} \\
\hline & Model 1 & Model 2 & Model 3 & Model 4 & Model 5 & Model 6 & Model 7 & Model 8 & Model 9 \\
\hline & $\begin{array}{l}3.26 \bullet \bullet \\
(0.12)\end{array}$ & $\begin{array}{l}3.08 \bullet \bullet \\
(0.15)\end{array}$ & $\begin{array}{l}3.21 \bullet \bullet \\
(0.13)\end{array}$ & $\begin{array}{l}3.42 \bullet \bullet \\
(0.15)\end{array}$ & $\begin{array}{l}3.59 \bullet \bullet \\
(0.19)\end{array}$ & $\begin{array}{l}3.21 \cdot \bullet \\
(0.13)\end{array}$ & $\begin{array}{l}3.09 \bullet \bullet \\
(0.17)\end{array}$ & $\begin{array}{l}2.58 \bullet \bullet \\
(0.19)\end{array}$ & $\begin{array}{l}3.07 \bullet \bullet \bullet \\
(0.18)\end{array}$ \\
\hline Local & & $\begin{array}{l}0.73 \bullet \bullet \\
(0.18)\end{array}$ & & & $\begin{array}{c}0.14 \\
(0.23)\end{array}$ & & & $\begin{array}{l}1.33 \bullet \bullet \\
(0.23)\end{array}$ & \\
\hline Cosmopolitan & & & $\begin{array}{c}0.21 \\
(0.14)\end{array}$ & & & $\begin{array}{l}0.45 \bullet \bullet \\
(0.17)\end{array}$ & & & $\begin{array}{l}-0.04 \\
(0.19)\end{array}$ \\
\hline Degrees of freedom & 2 & 3 & 3 & 2 & 3 & 3 & 2 & 3 & 3 \\
\hline $\begin{array}{l}\text { R-squared } \\
\mathrm{N}=485\end{array}$ & 0.07 & 0.15 & 0.05 & 0.04 & 0.07 & 0.04 & 0.06 & 0.19 & 0.03 \\
\hline
\end{tabular}

TABLE 3. Results of Team-Level and Individual-Level Regression Analysis for H2a/H2b, DV=External Knowledge

\begin{tabular}{|c|c|c|c|c|c|c|c|c|c|}
\hline & \multicolumn{3}{|c|}{$\begin{array}{l}\text { Total External Knowledge } \\
\text { (Team Level) }\end{array}$} & \multicolumn{3}{|c|}{$\begin{array}{l}\text { External Technical Knowledge } \\
\text { (Team Level) }\end{array}$} & \multicolumn{3}{|c|}{$\begin{array}{c}\text { External Country Knowledge } \\
\text { (Team Level) }\end{array}$} \\
\hline & Model 1 & Model 2 & Model 3 & Model 4 & Model 5 & Model 6 & Model 7 & Model 8 & Model 9 \\
\hline Constant & $\begin{array}{l}3.05 \bullet \bullet \bullet \\
(0.42)\end{array}$ & $\begin{array}{c}3.31 \bullet \bullet \\
(0.42)\end{array}$ & $\begin{array}{c}3.23 \bullet \bullet \\
(0.42)\end{array}$ & $\begin{array}{l}3.15 \bullet \bullet \\
(0.43)\end{array}$ & $\begin{array}{l}3.40 \bullet \bullet \\
(0.43)\end{array}$ & $\begin{array}{c}3.31 \bullet \bullet \\
(0.43)\end{array}$ & $\begin{array}{l}3.00 \bullet \bullet \\
(0.47)\end{array}$ & $\begin{array}{l}3.26 \cdot \bullet \bullet \\
(0.46)\end{array}$ & $\begin{array}{l}3.18 \cdot \bullet \\
(0.47)\end{array}$ \\
\hline No. of of Locals & $\begin{array}{l}0.12 \bullet \\
(0.05)\end{array}$ & & $\begin{array}{c}0.08 \\
(0.05)\end{array}$ & $\begin{array}{l}0.11 \bullet \\
(0.05)\end{array}$ & & $\begin{array}{c}0.08 \\
(0.06)\end{array}$ & $\begin{array}{l}0.12 \\
(0.06)\end{array}$ & & $\begin{array}{c}0.08 \\
(0.06)\end{array}$ \\
\hline No. of Cosmopolitans & & $\begin{array}{l}0.13 \bullet \bullet \\
(0.05)\end{array}$ & $\begin{array}{l}0.11 \bullet \\
(0.05)\end{array}$ & & $\begin{array}{l}0.11 \bullet \\
(0.05)\end{array}$ & $\begin{array}{l}0.09 \dagger \\
(0.05)\end{array}$ & & $\begin{array}{l}0.13 \bullet \bullet \\
(0.05)\end{array}$ & $\begin{array}{l}0.11 \bullet \\
(0.05)\end{array}$ \\
\hline \multirow{4}{*}{$\begin{array}{l}\text { Degrees of freedom } \\
\text { R-squared } \\
\mathrm{N}=96 \\
\end{array}$} & 8 & 8 & 9 & 8 & 8 & 9 & 8 & 8 & 9 \\
\hline & 0.06 & 0.09 & 0.12 & 0.07 & 0.09 & 0.11 & 0.07 & 0.10 & 0.12 \\
\hline & \multicolumn{3}{|c|}{$\begin{array}{l}\text { Total External Knowledge } \\
\text { (Individual Level) }\end{array}$} & \multicolumn{3}{|c|}{$\begin{array}{l}\text { External Technical Knowledge } \\
\text { (Individual Level) }\end{array}$} & \multicolumn{3}{|c|}{$\begin{array}{c}\text { External Country Knowledge } \\
\text { (Individual Level) }\end{array}$} \\
\hline & \begin{tabular}{|l|} 
Model 1 \\
\end{tabular} & Model 2 & Model 3 & Model 4 & Model 5 & Model 6 & Model 7 & Model 8 & Model 9 \\
\hline Constant & $\begin{array}{l}2.99 \cdot . \bullet \\
(0.10)\end{array}$ & $\begin{array}{c}3.10 \bullet \bullet \\
(0.13)\end{array}$ & $\begin{array}{l}2.98 \cdot \bullet \\
(0.11)\end{array}$ & $\begin{array}{l}2.85 \bullet \bullet \\
(0.11)\end{array}$ & $\begin{array}{l}2.95 \bullet \bullet \\
(0.15)\end{array}$ & $\begin{array}{l}2.83 \bullet \bullet \\
(0.12)\end{array}$ & $\begin{array}{l}3.12 \bullet \bullet \\
(0.11)\end{array}$ & $\begin{array}{l}3.25 \cdot \bullet \\
(0.14)\end{array}$ & $\begin{array}{l}3.12 \bullet \bullet \\
(0.11)\end{array}$ \\
\hline Local & & $\begin{array}{l}-0.05 \\
(0.16)\end{array}$ & & & $\begin{array}{l}-0.01 \\
(0.18)\end{array}$ & & & $\begin{array}{l}-0.09 \\
(0.17)\end{array}$ & \\
\hline Cosmopolitan & & & $\begin{array}{l}0.27 \bullet \\
(0.11)\end{array}$ & & & $\begin{array}{l}0.32 \bullet \bullet \\
(0.12)\end{array}$ & & & $\begin{array}{l}0.22 \dagger \\
(0.12)\end{array}$ \\
\hline Degrees of freedom & 2 & 3 & 3 & 2 & 3 & 3 & 2 & 3 & 3 \\
\hline $\begin{array}{l}\text { R-squared } \\
\mathrm{N}=485\end{array}$ & 0.01 & 0.01 & 0.03 & 0.00 & 0.01 & 0.03 & 0.01 & 0.01 & 0.03 \\
\hline
\end{tabular}

${ }^{\dagger} p<.10, \cdot p<.05, \cdot \bullet p<.01, \cdots p<0.001$ 
TABLE 4. Results of Team-Level Ordinal Logit Analysis for H3a/H3b, DV=Project Quality (n=96)

\begin{tabular}{|c|c|c|c|c|c|c|c|c|c|c|c|}
\hline & Model 1 & Model 2 & Model 3 & & Model 4 & Model 5 & Model 6 & & Model7 & Model 8 & Model 9 \\
\hline Total internal knowledge ${ }^{1}$ & $\begin{array}{c}0.24 \\
(0.54)\end{array}$ & $\begin{array}{c}0.16 \\
(0.49)\end{array}$ & $\begin{array}{c}0.22 \\
(0.54)\end{array}$ & Internal technical knowledge ${ }^{1}$ & $\begin{array}{c}0.07 \\
(0.43)\end{array}$ & $\begin{array}{c}0.14 \\
(0.43)\end{array}$ & $\begin{array}{c}0.18 \\
(0.44)\end{array}$ & Internal country knowledge ${ }^{1}$ & $\begin{array}{c}0.20 \\
(0.42)\end{array}$ & $\begin{array}{l}-0.16 \\
(0.37)\end{array}$ & $\begin{array}{c}0.03 \\
(0.43)\end{array}$ \\
\hline No. of Locals ${ }^{1}$ & -0.45 & & -0.50 & No. of Locals ${ }^{1}$ & $-0.54 \dagger$ & & $-0.67 \bullet$ & No. of Locals ${ }^{1}$ & -0.46 & & -0.49 \\
\hline No. of Cosmopolitans ${ }^{1}$ & $(0.31)$ & $\begin{array}{c}0.16 \\
(0.26)\end{array}$ & $\begin{array}{c}(0.32) \\
0.23 \\
(0.57)\end{array}$ & No. of Cosmopolitans ${ }^{1}$ & $(0.30)$ & $\begin{array}{c}0.08 \\
(0.26)\end{array}$ & $\begin{array}{c}(0.31) \\
0.33 \\
(0.27)\end{array}$ & No. of Cosmopolitans ${ }^{1}$ & & $\begin{array}{c}0.20 \\
(0.27)\end{array}$ & $\begin{array}{c}(0.33) \\
0.26 \\
(0.28)\end{array}$ \\
\hline $\begin{array}{l}\text { No. of Locals * } \\
\text { Total internal knowledge }\end{array}$ & $\begin{array}{l}-0.85 \dagger \\
(0.52)\end{array}$ & & $\begin{array}{l}-0.61 \\
(0.27)\end{array}$ & $\begin{array}{l}\text { No. of Locals * } \\
\text { Internal technical knowledge }\end{array}$ & $\begin{array}{l}-0.96 \bullet \\
(0.44)\end{array}$ & & $\begin{array}{l}-1.27 \bullet \\
(0.52)\end{array}$ & $\begin{array}{l}\text { No. of Locals * } \\
\text { Internal country knowledge }\end{array}$ & $\begin{array}{l}-0.17 \\
(0.38)\end{array}$ & & $\begin{array}{c}0.02 \\
(0.40)\end{array}$ \\
\hline $\begin{array}{l}\text { No. of Cosmopolitans * } \\
\text { Total internal knowledge }\end{array}$ & & $\begin{array}{l}-0.75 \dagger \\
(0.43)\end{array}$ & $\begin{array}{l}-0.50 \\
(0.48)\end{array}$ & $\begin{array}{l}\text { No. of Cosmopolitans * } \\
\text { Internal technical knowledge }\end{array}$ & & $\begin{array}{l}-0.23 \\
(0.36)\end{array}$ & $\begin{array}{c}0.32 \\
(0.42)\end{array}$ & $\begin{array}{l}\text { No. of Cosmopolitans * } \\
\text { Internal country knowledge }\end{array}$ & & $\begin{array}{l}-0.62 \dagger \\
(0.33)\end{array}$ & $\begin{array}{l}-0.58 \dagger \\
(0.34)\end{array}$ \\
\hline Degrees of freedom & 11 & 11 & 13 & Degrees of freedom & 11 & 11 & 13 & Degrees of freedom & 11 & 11 & 13 \\
\hline LL chi-squared ratio test ${ }^{2}$ & $27.76 \bullet \bullet$ & $25.16 \bullet \bullet$ & $29.24 \cdot \bullet$ & LL chi-squared ratio test ${ }^{2}$ & $29.32 \bullet \bullet$ & $22.28 \bullet$ & $31.28 \cdot \bullet$ & LL chi-squared ratio test ${ }^{2}$ & $24.72 \bullet$ & $25.32 \bullet \bullet$ & $27.80 \bullet$ \\
\hline Pseudo R-squared & 0.16 & 0.14 & 0.17 & Pseudo R-squared & 0.17 & 0.12 & 0.18 & Pseudo R-squared & 0.18 & 0.14 & 0.16 \\
\hline
\end{tabular}

\section{TABLE 5. Results of Team-Level Ordinal Logit Analysis for H4a/H4b, DV=Project Quality (n=96)}

\begin{tabular}{|c|c|c|c|c|c|c|c|c|c|c|c|c|}
\hline & Model 1 & Model 2 & Model 3 & Model 4 & Model 5 & Model 6 & Model 7 & Model 8 & Model 9 & Model 10 & Model 11 & Model 12 \\
\hline Total external knowledge ${ }^{1}$ & $\begin{array}{c}0.82 \\
(0.59)\end{array}$ & $\begin{array}{c}0.61 \\
(0.59)\end{array}$ & $\begin{array}{c}0.75 \\
(0.60)\end{array}$ & $\begin{array}{c}0.83 \\
(0.59)\end{array}$ & $\begin{array}{c}0.71 \\
(0.59)\end{array}$ & $\begin{array}{c}0.85 \\
(0.61)\end{array}$ & $\begin{array}{c}0.81 \\
(0.59)\end{array}$ & $\begin{array}{c}0.66 \\
(0.59)\end{array}$ & $\begin{array}{c}0.81 \\
(0.60)\end{array}$ & $\begin{array}{l}3.22 \bullet \bullet \\
(1.06)\end{array}$ & $\begin{array}{l}2.41 \bullet \bullet \\
(0.86)\end{array}$ & $\begin{array}{c}4.38 \cdot \bullet \bullet \\
(1.36)\end{array}$ \\
\hline No. of Locals ${ }^{1}$ & $\begin{array}{l}-0.52 \dagger \\
(0.30)\end{array}$ & & $\begin{array}{c}-0.56 \dagger \\
(0.31)\end{array}$ & $\begin{array}{c}-0.61 \dagger \\
(0.35)\end{array}$ & & $\begin{array}{c}-0.55 \\
(0.37)\end{array}$ & $\begin{array}{l}-0.50 \dagger \\
(0.30)\end{array}$ & & $\begin{array}{l}-0.70 \bullet \\
(0.32)\end{array}$ & $\begin{array}{l}-0.71 \dagger \\
(0.38)\end{array}$ & & $\begin{array}{l}-0.83 \bullet \\
(0.42)\end{array}$ \\
\hline No. of Cosmopolitans ${ }^{1}$ & & $\begin{array}{c}0.05 \\
(0.25)\end{array}$ & $\begin{array}{c}0.16 \\
(0.27)\end{array}$ & & $\begin{array}{l}-0.09 \\
(0.27)\end{array}$ & $\begin{array}{c}0.00 \\
(0.30)\end{array}$ & & $\begin{array}{c}0.06 \\
(0.25)\end{array}$ & $\begin{array}{c}0.35 \\
(0.28)\end{array}$ & & $\begin{array}{c}0.20 \\
(0.30)\end{array}$ & $\begin{array}{c}0.53 \\
(0.35)\end{array}$ \\
\hline No. of Locals-squared & & & & $\begin{array}{c}0.08 \\
(0.16)\end{array}$ & & $\begin{array}{l}-0.02 \\
(0.17)\end{array}$ & & & & $\begin{array}{c}0.86 \bullet \\
(0.37)\end{array}$ & & $\begin{array}{l}1.06 \bullet \\
(0.44)\end{array}$ \\
\hline No. of Cosmopolitans-squared & & & & & $\begin{array}{c}0.23 \\
(0.18)\end{array}$ & $\begin{array}{c}0.21 \\
(0.17)\end{array}$ & & & & & $\begin{array}{c}0.29 \dagger \\
(0.15)\end{array}$ & $\begin{array}{c}0.33 \\
(0.25)\end{array}$ \\
\hline No. of Locals * Total external knowledge & & & & & & & $\begin{array}{c}-0.45 \\
(0.57)\end{array}$ & & $\begin{array}{l}-1.36 \bullet \\
(0.67)\end{array}$ & $\begin{array}{c}0.48 \\
(0.81)\end{array}$ & & $\begin{array}{l}-0.54 \\
(0.94)\end{array}$ \\
\hline No. of Cosmopolitans * Total external knowledge & & & & & & & & $\begin{array}{c}0.84 \\
(0.59)\end{array}$ & $\begin{array}{l}1.74 \bullet \\
(0.71)\end{array}$ & & $\begin{array}{c}0.84 \\
(0.61)\end{array}$ & $\begin{array}{l}1.47 \dagger \\
(0.80)\end{array}$ \\
\hline No. of Locals-squared *Total external knowledge & & & & & & & & & & $\begin{array}{c}-2.75 \bullet \bullet \\
(0.97)\end{array}$ & & $\begin{array}{c}-3.15 \bullet \bullet \\
(1.18)\end{array}$ \\
\hline No. of Cosmopolitans-squared * Total external knowledge & & & & & & & & & & & $\begin{array}{c}-1.54 \bullet \bullet \\
(0.56)\end{array}$ & $\begin{array}{l}-0.85 \\
(0.68)\end{array}$ \\
\hline Degrees of freedom & 10 & 10 & 11 & 11 & 11 & 13 & 11 & 11 & 13 & 13 & 13 & 17 \\
\hline LL chi- squared ratio test ${ }^{2}$ & $25.04 \bullet \bullet$ & $22.04 \bullet$ & $25.38 \bullet \bullet$ & $25.30 \bullet \bullet$ & $24.46 \bullet$ & $27.86 \bullet \bullet$ & $25.66 \bullet \bullet$ & $24.10 \bullet$ & $32.64 \bullet \bullet$ & 39.32••• & $33.58 \bullet \bullet$ & $49.06 \bullet • •$ \\
\hline Pseudo R-squared & 0.14 & 0.12 & 0.14 & 0.14 & 0.14 & 0.14 & 0.14 & 0.14 & 0.14 & 0.23 & 0.20 & 0.30 \\
\hline
\end{tabular}

${ }^{\dagger} p<.10, \cdot p<.05, \cdots p<.01, \cdots p<0.001 ;{ }^{1}$ Variable is centered by subtracting the mean; ${ }^{2}$ Compared to base model with cut points only, LL=-77.29. 
${ }^{\mathrm{i}}$ It is theoretically possible for an individual to have broad experience in many countries as well as deep experience in the project country, but this paper focuses only on those who are either cosmopolitans or locals or neither, for conceptual clarity and also because individuals who qualified as both were rare in the empirical dataset.

${ }^{\text {ii }}$ Knowledge can also be acquired through trial-and-error or experimental learning, but this form of knowledge acquisition is only analytically separable in teams that work together on multiple projects. In teams that are not stable across projects, it simply adds to the knowledge that the individual members bring with them to a new project.

iii The team leader was usually centrally involved in the project work, and therefore the phrase "team members" hereafter refers to the leader as well as the members.

${ }^{\text {iv }}$ Quorum had well-established procedures for evaluating the quality of eventual project outcomes, such as increases in life expectancy or literacy rates, but this three-year-old initiative focused on monitoring the quality of project outputs at the point of delivery to the client, prior to implementation. The links between the work of Quorum teams and the quality of their project outcomes could be tenuous but the quality of project outputs was a more direct result of their work. This was a central reason for Quorum's substantial investment in its quality monitoring initiative.

${ }^{v}$ The quality dimensions for financial projects included the quality of the project concept, technical, environmental, stakeholder, financial, institutional, and risk analyses, and readiness for implementation; those for technical projects included their strategic relevance and timeliness, internal quality, presentation, and likely impact. Continuous project quality ratings constructed by summing each project's scores on its underlying quality dimensions correlated highly with the ordinal project quality ratings $(r=0.86)$, and generated the same pattern of results. I report the results from the ordinal ratings because these were considered by Quorum to best reflect overall project quality.

${ }^{\text {vi }}$ The thresholds were those that the qualitative and quantitative data indicated were appropriate at Quorum, but different thresholds may be appropriate in other organizational settings. Sensitivity analyses indicated that the models were robust to minor modifications in the thresholds used, such as variations in the number of countries lived and worked in required to qualify as a cosmopolitan or exclusion of individuals who qualified as locals but had lived and worked in the client country for less than a year. The appropriateness of the thresholds was also supported by the emergence (rather than imposition) of a frequency distribution of locals, cosmopolitans, and others that had face validity in the research setting, where the widely held view among teams, senior leaders, and human resource managers that the organization employed some individuals who were very deeply embedded in the client countries, more individuals who were very highly internationally experienced, and many who fell somewhere in between.

vii It was rare but not impossible for an individual to qualify as both: 25 individuals in the sample met all six criteria. The project quality ratings for the teams to which these members belonged followed the same distribution as those for the full sample of teams, and omitting them from the analyses did not change the results.

viii The available data could not conclusively establish whether locals or cosmopolitans were more or less likely to return their surveys than non-locals or non-cosmopolitans, but the proportion of respondents who qualified as locals was positively correlated with the proportion of team members who returned their surveys $(r=0.26$, $p<0.05)$, while the proportion who qualified as cosmopolitans was not correlated with the proportion of team members who returned their surveys ( $\mathrm{r}=-0.02$, n.s.). This suggests that locals were more likely to respond to the survey than nonlocals, but cosmopolitans were not more or less likely to respond than non-cosmopolitans. Under-estimation of the number of cosmopolitans on the team thus was more likely than under-estimation of the number of locals.

${ }^{\text {ix }}$ Because calculation and interpretation of interaction effects in nonlinear regression models can be problematic (Ai and Norton 2003), I also generated the marginal effects for the interaction terms and ran the models using an ordinary least squares specification. These two alternative approaches both generated the same pattern of results.

${ }^{x}$ Including an additional control variable for the number of late respondents did not change the results in any of the models; controlling for the numbers of core team members and external consultants did not affect the results either.

${ }^{x i}$ Introducing the locals-squared and cosmopolitans-squared variables revealed no curvilinear effects, so these variables are omitted in the models reported here. This was also the case for the models presented in Tables 3 and 4. 